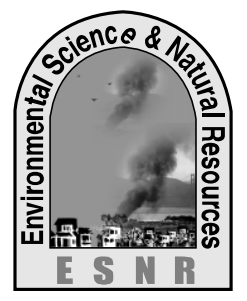

J. Environ. Sci. \& Natural Resources, 6(1): 159 - 162, 2013

ISSN 1999-7361

\title{
Effect of Different Source of Nutrients on the Performance, Growth and Quality of Summer Onion
}

\author{
M. G. Azam ${ }^{1}$, M. Islam ${ }^{1}$, M. A. Gulandaz ${ }^{1}$ and J. A. Mahmud ${ }^{2}$ \\ ${ }^{1}$ Regional Agricultural Research Station, Bangladesh Agricultural Research Institute, Jessore, ${ }^{2}$ On-Farm \\ Research Division, Regional Agricultural Research Station, Bangladesh Agricultural Research Institute, \\ Jessore
}

\begin{abstract}
The field experiments were conducted for one season rabi 2008-09 at the Multilocation testing site Magura on calcareous soil to study the effect of integrated nutrient management on the growth and yield of onion (cv. BARI piaj 2). The experiment was laid out in a RCB design. There were five treatments involving four inorganic levels and organic levels another absolute control (no manure and no NPK). Higher level of inorganic $\mathrm{T}_{1}$ i.e., (120-45-85-40 kg ha ${ }^{-1} \mathrm{NPK}$ S+ $5 \mathrm{t} / \mathrm{ha}$ CD) produced significantly higher bulb yield (18.76 t/ha) which was on par with $\mathrm{T}_{4}(17.87 \mathrm{t} / \mathrm{ha})$ i.e., $5 \mathrm{t} /$ ha poultry manure + remaining amount from inorganic fertilizer $T_{2}$. The results also indicated that the same treatments recorded the highest single bulb weight, bulb yield as well as gross returns and MBCR (7.14) as compared to other treatments.
\end{abstract}

Key words: Growth, Inorganics, Organics, Onion, Yield

\section{Introduction}

Onion (Allium cepa. $\mathrm{L}$ ) is one of the most important commercial spices in Bangladesh. It stands second in respect of area and production in Bangladesh. At present Bangladesh produces12 lakh metric tons of onion from 1.42 lakh hectares of land (DAE, 2009). The average production is 5.72 ton/ha. The annual national demand of onion is about 16 lakh ton. There is a running short is about 4 lakh ton (Annon., 2006).. Every year Bangladesh import huge amount of onion from the neighboring countries and expend about 500 to 600 crore taka. (Annon., 2005-06). However, the productivity of onion in Bangladesh is quite low as compared to world's productivity. So, there is an acute shortage of onion in relation to its requirement. This can be done by many ways of which the most important are the continuous and liberal use of inorganic fertilizer alone affects soil health and thus resulting in lower yield with poor quality produce (Mamatha, 2006). Plant nutrition plays an important role for enhancing yield and quality in onion. The cost of inorganic fertilizers has been enormously increasing to an extent that they are out of reach of the poor, small and marginal farmers.

Integrated Plant Nutrition System (IPNS) is 'the management of all available plant nutrient sources, organic and inorganic, to provide optimum and sustainable crop production conditions within the prevailing farming system' (BARC, 2005). In Bangladesh, Several scientists were revealed that the integrated nutrient management with organic and inorganic fertilizers to conserve the soil health and to get good quality produce. Although, the weather conditions seem to be friendly for the proper growth of onion but research work is very insufficient.
Organic material such as farmyard manure, mustard oil cake, vermicompost, poultry manure and bio-slurry improve soil physical and chemical properties that are important for plant growth (Synman et al., 1998). Many researchers have found that addition of animal manure resulted in higher onion yield and nutrient uptake compared to NPK fertilizer. (Kumar et al., 2001, Rumpel, 1998 and Sharma et al., 2003). Mixture of chicken manure and bio-fertilizer increases the yield of onion and enriched nutrient content in tuber was reported by Shaheen $e t$ al., (2007). Keeping in view these aspects, the present research work was initiated to determine the ideal integrated nutrient management package on growth, yield and quality of onion.

\section{Materials and Methods}

The experiment was carried out in the farmer's field at the MLT site Magura during 2008-09. Four different treatments with control and six dispersed replications were conducted in 15 plots. $T_{1}$ $($ Recommended from Ph.D work $)=(120-45-85-40 \mathrm{~kg}$ ha $^{-1}$ NPK S+ 5 tha CD), $T_{2}$ (Recommended from spice research center $)=\left(90-55-75-20 \mathrm{~kg} \mathrm{ha}^{-1} \mathrm{NPKS}\right)$, $\mathrm{T}_{3}($ IPNS $)=3 \mathrm{t} / \mathrm{ha}$ poultry manuare + remaining amount from inorganic fertilizer $\mathrm{T}_{2}, \mathrm{~T}_{4}(\mathrm{IPNS})=5 \mathrm{t} / \mathrm{ha}$ poultry manuare + remaining amount from inorganic fertilizer $\mathrm{T}_{2}$ and $\mathrm{T}_{5}=\left(00-00-00-00 \mathrm{~kg} \mathrm{ha}^{-1} \mathrm{NPKS}\right)$.

The unit plot size was $2 \mathrm{~m} \times 2 \mathrm{~m}$. Fifty days old seedling BARI Piaj-02 was planted on 07 April 2008 maintaining the row spacing $15 \mathrm{~cm}$ and plant to plant distance $10 \mathrm{~cm}$. Fertilizers were applied as per treatments. Total cowdung /poultry manure, TSP and Gypsum were used at final land preparation. $1 / 3^{\text {rd }}$ urea and $1 / 2$ MP were used as $1^{\text {st }}$ top dress on 19 April 
2008. $1 / 3^{\text {rd }}$ urea were used as $2^{\text {nd }}$ top dress on 30 April 2008 and rest $1 / 3$ rd urea and $1 / 2$ MP were used as $3^{\text {rd }}$ top dress on May 2008. The crop was irrigated thrice April 8, 19 and 27 of 2008 and harvested on 10 June 2008. The data were collected; analyzed statistically and mean separation was done by DMRT. Data were recorded by selecting plants randomly from each treatment plot and average was calculated for the statistical analysis. The parameters under study were plant height $(\mathrm{cm})$, number of leaves per plant, Single Bulb weight $(\mathrm{g})$, No. of bulb/kg, bulb diameter $(\mathrm{cm})$, and total yield per hectare (tones). The mean data were subjected to the Analysis of Variance Technique (Steel and Torrie, 1984) using the "MSTATC" Computer software package. Duncan's Multiple Range Tests (Duncan, 1955) was adopted for comparing their means among the treatments showing significant difference. Here, total variable cost (TVC) estimate through fertilizer price.

\section{Results and Discussions}

Data about effects of organic and chemical fertilizer on onion yield contributing criteria are given below in Table 1. The highly significant data pertaining to plant height as affected by different application of treatments on onion. The $\mathrm{T}_{1}$ treatment resulted in tallest plant height $(39.57 \mathrm{~cm})$ closely related to $T_{4}$ and $\mathrm{T}_{2}$ treatments with $34.17 \mathrm{~cm}$ and $33.67 \mathrm{~cm}$ plant height respectively. Similarly, significantly higher plant height in onion with application of vermin compost was reported by Reddy and Reddy (2005). Higher levels of FYM significantly increased the plant height, number of leaves per plant (Reddy and Reddy, 2005) and leaf area per plant (Lal et al., 2002) in onion. The maximum leaves per plant was observed from the treatment $T_{1}$ (7.83) which was statistically differ from the other treatments.
The data regarding single bulb weight was observed that all the treatments significantly affected bulb weight. The highest single bulb weight was obtained from the treatment $\mathrm{T}_{1}(20.33 \mathrm{gm})$ which was statistically similar with $\mathrm{T}_{4}(19.00 \mathrm{gm})$. The lowest single bulb weight was obtained from the treatment $\mathrm{T}_{5}(12.00 \mathrm{gm})$.

The data pertaining to number of bulb per $\mathrm{kg}$ showed that all the treatments affected significantly number of bulb per $\mathrm{kg}$. The treatment $\mathrm{T}_{5}(82.67)$ showed highest number of bulb per $\mathrm{kg}$ followed by $\mathrm{T}_{3}$ and $\mathrm{T}_{2}$ treatments. The lowest number of bulb per $\mathrm{kg}$ was observed from $T_{1}$ (49.67) treatment. Increased bulb weight with increased inorganic levels was also reported by Varul et al., (1997).

There are no significantly different on bulb diameter as affected by different treatments. The highest bulb diameter 3.87 from treatment $\mathrm{T}_{1}$ followed by $\mathrm{T}_{2}(3.61)$ and $\mathrm{T}_{4}$ (3.54) treatments. Mamatha, (2006) observed the highest bulb diameter with the application of FYM + vermicompost in onion. Similar effect was also observed in bitter gourd (Samuvel, 1984). The yield was significantly influenced by different sources of nutrients. Significantly highest yield was recorded from the $T_{1}(18.76 \mathrm{t} / \mathrm{ha})$ treatment which was statistically similar with $\mathrm{T}_{4}(17.87 \mathrm{t} / \mathrm{ha})$ and $\mathrm{T}_{3}(16.46$ $\mathrm{t} /$ ha) and lowest yield was 11.88 from $\mathrm{T}_{5}$ treatment. This application increased yield by $24 \%$ compared to the control plots. Similar result was found also by Rather et al., (2003), Sharma et al., (2003), Kumar et al., (2001), Dixit (1997) and Mallanagouda et al., (1995) but Akoun (2005), Agudelo and Casierra (2004), Blay et al., (2002), Rumpel (1998), Singh et al., (1997), and Vural et al., (1987) reported the opposite of the others.

Table 1. Effect of organic and inorganic fertilizer in the yield of summer onion

\begin{tabular}{l|c|c|c|c|c|c}
\hline Treatments & $\begin{array}{c}\text { Plant } \\
\text { Height } \\
(\mathrm{cm})\end{array}$ & $\begin{array}{c}\text { Leave/plant } \\
(\mathrm{no})\end{array}$ & $\begin{array}{c}\text { Single Bulb } \\
\text { weight }(\mathrm{g})\end{array}$ & $\begin{array}{c}\text { No. of } \\
\text { bulb/kg }\end{array}$ & $\begin{array}{c}\text { Bulb diameter } \\
(\mathrm{cm})\end{array}$ & $\begin{array}{c}\text { Yield } \\
(\mathrm{t} / \mathrm{ha})\end{array}$ \\
\hline $\mathrm{T}_{1}$ & $39.57 \mathrm{a}$ & $7.83 \mathrm{a}$ & $20.33 \mathrm{a}$ & $49.67 \mathrm{c}$ & 3.87 & $18.76 \mathrm{a}$ \\
$\mathrm{T}_{2}$ & $33.67 \mathrm{~b}$ & $6.70 \mathrm{ab}$ & $16.33 \mathrm{bc}$ & $60.67 \mathrm{bc}$ & 3.61 & $15.42 \mathrm{~b}$ \\
$\mathrm{~T}_{3}$ & $32.60 \mathrm{~b}$ & $6.03 \mathrm{~b}$ & $15.67 \mathrm{c}$ & $63.67 \mathrm{~b}$ & 3.44 & $16.46 \mathrm{ab}$ \\
$\mathrm{T}_{4}$ & $34.17 \mathrm{~b}$ & $6.27 \mathrm{~b}$ & $19.00 \mathrm{ab}$ & $55.00 \mathrm{bc}$ & 3.54 & $17.87 \mathrm{a}$ \\
$\mathrm{T}_{5}$ & $27.73 \mathrm{c}$ & $5.33 \mathrm{~b}$ & $12.00 \mathrm{~d}$ & $82.67 \mathrm{a}$ & 2.86 & $11.88 \mathrm{c}$ \\
\hline $\mathrm{CV}(\%)$ & 5.15 & 10.73 & 9.55 & 10.03 & 10.70 & 21.71 \\
F-test & $* *$ & $*$ & $* *$ & $* *$ & 0.70 & $* *$ \\
\hline
\end{tabular}

At higher level of organics, improved soil physical conditions might have resulted in better root growth, nutrient absorption and better bulb development. Increased bulb yield were noticed by several workers viz; Varul et al., (1997), Singh et al., (1997) and Lal et al., (2002) with increased FYM levels. The yield parameters like bulb equatorial diameter, polar diameter and bulb weight also increased significantly at higher levels of organics. Significantly higher bulb size was recorded by Lal et al., (2002).

Similarly, significantly higher bulb equatorial diameter due to integrated nutrient management 
(INM) was recorded by Mallanagouda et al., (1995) and Varul et al. (1997).

The highest gross returns of Tk.281400 was obtained with $\mathrm{T}_{1}$ the application of (120-45-85-40 $\mathrm{kg} \mathrm{ha}^{-1} \mathrm{NPK}$ $\mathrm{S}+5 \mathrm{t} / \mathrm{ha} \mathrm{CD})$ followed by the treatments $\mathrm{T}_{4}(\mathrm{Tk}$. 268050) and $\mathrm{T}_{3}$ (Tk. 246900).
The treatment $T_{1}$ showed maximum marginal benefit cost ratio (MBCR) 7.14 and lowest was obtained from the treatment $\mathrm{T}_{2}$ (4.66)

Table 2. Treatment wise economics of summer onion as influenced by different manure and fertilizers

\begin{tabular}{c|c|c|c|c}
\hline Treatments & Gross return (Tk./ha) & $\begin{array}{c}\text { TVC } \\
\text { (Tk./ha) }\end{array}$ & $\begin{array}{c}\text { MVP } \\
\text { (over control) }\end{array}$ & $\begin{array}{c}\text { MVC } \\
\text { (over control) }\end{array}$ \\
\hline $\mathrm{T}_{1}$ & 281400 & 14451 & 103200 & 14451 \\
$\mathrm{~T}_{2}$ & 231300 & 11400 & 53100 & 11400 \\
$\mathrm{~T}_{3}$ & 246900 & 13376 & 68700 & 13376 \\
$\mathrm{~T}_{4}$ & 268050 & 14690 & 89850 & 14690 \\
$\mathrm{~T}_{5}$ & 178200 & 0 & 0 & 0 \\
\hline
\end{tabular}

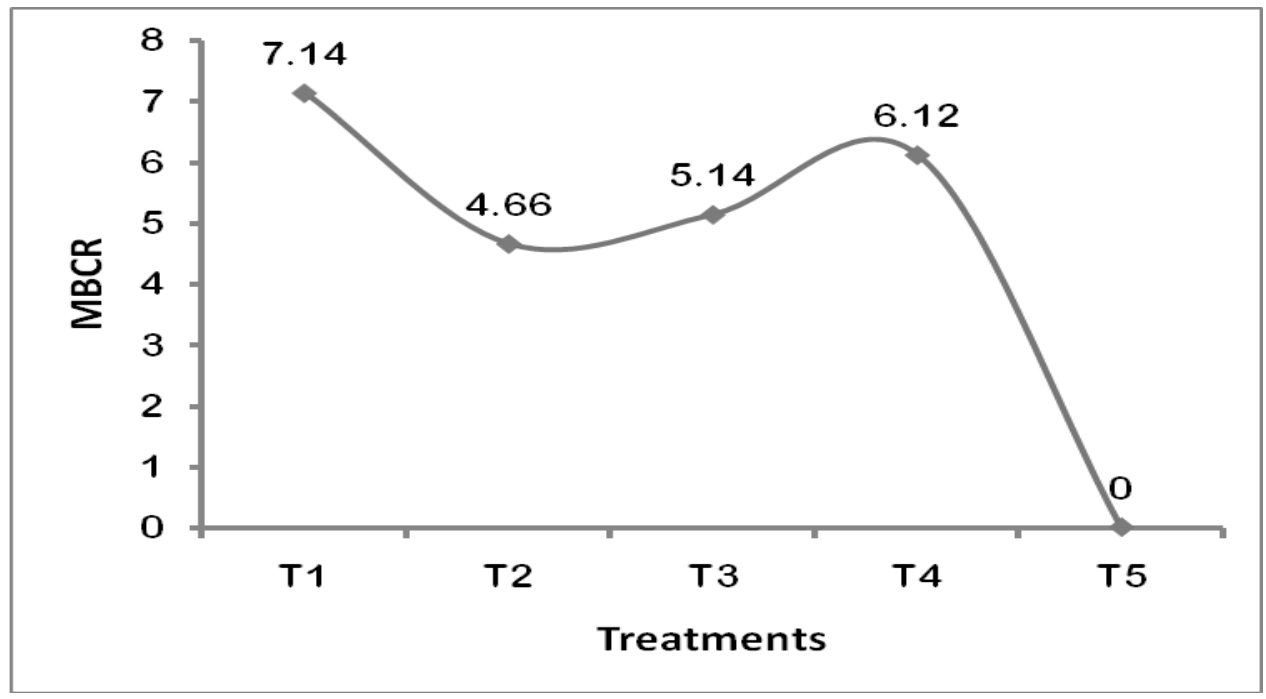

Fig.1. Marginal benifit cost ratio on summer onion production as influenced by different organic and inorganic fertilizer

\section{Conclusions}

With these results it can be concluded that higher level of inorganics i.e., $\mathrm{T}_{1}$ (Recommended from $\mathrm{Ph} . \mathrm{D}$ work $)=\left(120-45-85-40 \mathrm{~kg} \mathrm{ha}^{-1} \mathrm{NPK} \mathrm{S}+5 \mathrm{t} / \mathrm{ha}\right.$ CD), and higher levels of organics viz., $\mathrm{T} 4$ and $\mathrm{T}_{3}$ recorded higher bulb yield individually. This was reflected in growth parameters like plant height, number of leaves and Single Bulb weight as well as yield parameters. The treatment $\mathrm{T}_{1}$ showed maximum gross return (281400 tk/ha) and lowest was obtained from the treatment $\mathrm{T}_{5}(178200 \mathrm{tk} / \mathrm{ha})$.

\section{Refferences}

Agudelo, B. M. Y. and Casierra, P. F. 2004. Effect of Mycorrhizae and Manure Fertilization and Yield and Quality of Onion. Revista-
Facultad Nacional de Agronomia Medellin. 57:1; 2189-2202.

Akoun, J. 2005. Effect plant density and manure on the yield and yield components the common onion (Allium cepa L.) var. Nsukka red. Hort Sci., 9: 43-48.

Anonymous.2010.http://www.slidefinder.net/t/life_yo ur_soil/ introduction soil__microbiology/ 1116901. Environmental soils. cas. psu. edu. 2009. http://www.tuik.gov.tr.

Anonymous, 2005-06. Spices research center studies. BARI ANNUAL REPORT. Bangladesh Agricultural Research Institute, Joydebpur, Gazipur, Bangladesh. 
Anonymous. 2006. Bangladesh Bureau of Statistics. Monthly Statistical Bulletin of Bangladesh. January, Statistics Div., Ministry of Planning, Govt. People's Repub. Bangladesh.

BARC, 2005. Bangladesh Agricultural Research Council, Fertilizer Recommendation Guide2005. P 52.

Blay, E. T.; Danquahe, Y.; Ofosu, A. J. and Ntumy, J. K. 2002. Effect of Poultry Manure and/or Inorganic Fertilizer on the Yield of Shallot (Allium cepa var. aggregatum). Adv. in Hort. Sci., 1: 13-16.

DAE (Department of Agricultural extension), 2009. spices statistics. Extension Statics Retrieved May 20, 2010 from http/www.dae.gov.bd/ index. php? area=statistics\& action=sta_oil.html.

Dixit, S. P. 1997. Response of onion (Allium cepa L.) to nitrogen and farmyard manure in dry temperate high hills of Himachal Pradesh. Indian J. Agric. Sci., 67(5): 222223.

Duncan, D. B. 1955. Multiple range and multiple $F$ test. Biometrics, 11: 1-42.

Kumar, A.; Singh , R. and Chhillar, R. K. 2001. Influence of nitrogen and potassium application on growth, yield and nutrient uptake by onion (Allium cepa L.). Indian $J$. Agron., 46 (4): 742-746.

Lal, S.; Yadav, A. C.; Mangal, J. L.; Avtar, S. and Batra, V. K. 2002, Effects of FYM and irrigation levels on growth and yield of onion cv. Hisar-2. Haryana J. Hort. Sci., 31(3-4): 256-258.

Mallanagouda, B.; Sulikeri, G. S.; Hulamani, N. C.; Murthy. B.G.and Madalgeri, B. B. 1995. Effect of NPK and FYM on growth parameters of onion, garlic and coriander. Univ. Agric. Sci. (Bangalore), 24 (11): 212213.

Mamatha, H. N. 2006. Effect of organic and inorganic sources of nitrogen on yield and quality of onion (Allium cepa L.) and soil properties in Alfisol. M. Sc. (Agri.) Thesis, Univ. Agric. Sci., Dharwad, India.
Rather, S. A.; Ahmed, N. and Chattoo, M. A. 2003. Response of Onion to Microbial Inoculation and Chemical Nitrogen. Haryana J. Hort. Sci. 32:3/4. 270-271.

Reddy, K. C. and Reddy, K. M. 2005. Differential levels of evermicompost and nitrogen on growth and yield in onion (Allium cepa L.) radish (Raphanus sativus L.) cropping system. J. Res., ANGRAU., 33 (1): 11-17.

Rumpel, J. 1998. Effect of long-term organic, mineral, and combined organic-mineral fertilization on yield of onions (Allium cepa L.) grown from seeds. Biuletyn Warzywniczy, 48: 5-15.

Samuvel, G. 1984. Studies on the interaction between VAM and phosphobacterium in certain vegetable crop plants. M. Sc. (Agri.) Thesis, Tamil Nadu Agric. Univ., Coimbatore (India).

Shaheen, A.; Fatma, M.; Rizk, A. and Singer S. M. 2007. Growing Onion Plants without Chemical Fertilization. Res. J. Agr. Biol. Sci., 3(2): 95-104.

Sharma, R. P.; Datt, N. and Sharma, P. K. 2003. Combined Application of Nitrogen, Phosphorus, Potassium and Farmyard Manure in Onion Under High Hills, Dry Temperate Conditions Of North-Western Himalayas. Indian J. Agr. Sci., 73:4: 225227.

Singh, L.; Bhonde, S. R. and Mishra, V. K. 1997. Effect of different organic manures and inorganic fertilizers on yield and quality of rabi onion. News Let. - Natl. Hort. Res. Dev. Foundation, 17 (3): 1-3 1997.

Snyman, H. G.; Jong, D.E. and Aveling, T. A. S. 1998. The stabilization of sewage sludge applied to agricultural land and the effects on maize seedlings. Water Sci.Technol., 38 (2): 87-95.

Steel, R. G. D. and Torrie, T. H. 1984. Principles and Procedures of Statistics. 2nd Edn. McGraw Hill Book Co., Singapore, pp: 172-177.

Vural, H.; Eser, B.; Özzambak, E.; Eiyok, D.; Tüzel, Y. and Yolta, T. 1987. A Study on Determining Degrees of Conformity of Planting the seed to be produced directly with Native Onion Varieties. Ege. Res. Fund, Res. Report, no: 051. 